\title{
Problematika schopnosti poskytnout informovaný souhlas v kontextu posuzování způsobilosti k právnímu jednání*
}

\section{Competence to Consent to Treatment and its Relationship to Legal Capacity}

\author{
Tomáš Doležal**, Adam Doležal ${ }^{* * *}$
}

\begin{abstract}
Abstrakt
Tento článek se vènuje problematice schopnosti pacienta udèlit informovaný soublas $k$ poskytnutí zdravotnich služeb. Tato problematika je analyzována v kontextu posuzováni zpisobilosti k právnimu jednáni v rámci občanskébo zákoniku a snaži se poukázat na skutečnost, že striktni aplikace pravidel o zpioisobilosti k právnimu jednání může v kontextu udělování informovanébo soublasu být pro nèkteré osoby neprimèrenè omezujici. Proto se článek snaži nabidnout vhodnèjš̀ rèsené, které by lépe chránilo zájmy dotčených subjektui. V rámci nalézáni toho réséní jsou pak podrobně analyzovány teoretické koncepty pro stanoveni zpuisobilosti človèke jednat, tj. pro posuzováni jeho kompetence. Na zákeladě krátké komparace článek ukazuje, že v radè státu je problematika schopnosti pacienta udèlit informovaný soublas posuzována oddèleně od jeho zpuisobilosti k právnímu jednáni a je více kontextuálně vymežena.
\end{abstract}

Klíčová slova

Informovaný soublas; kompetence; zpisobilost ke právnímu jednání.

\section{Abstract}

This article addresses the issue of a patient's ability to consent to treatment. This issue is analyzed in the context of the assessment of legal capacity under the Civil Code and seeks to highlight the fact that the strict application of the rules on legal capacity may be unduly restrictive for some people in the context of giving informed consent.

Therefore, the article seeks to offer a more appropriate solution that would better protect the interests of the subjects concerned. In this context are analyzed theoretical concepts of competence in detail to determine a person's capacity to act, i.e. to assess their competence.

Based on a brief comparison, the article shows that in some states, the issue of a patient's ability to consent (competence) is considered separately from their legal capacity to act and is more contextually defined.

Keywords

Informed Consent; Competence; Legal Capacity.

Tento článek byl vypracován s podporou GAČR v rámci grantového projektu 18-23804S.

** Doc. JUDr. Tomáš Doležal, Ph.D., LL.M., Ústav státu a práva AV ČR, v.v.i. / Institute of State and Law of the Czech Academy of Sciences, Czech Republic / E-mail: tomas.dolezal@ilaw.cas.cz / ORCID: 0000-0002-2545-4549 / Research ID: 57223291718

*** JUDr. Adam Doležal, Ph.D., LL.M., Ústav státu a práva AV ČR, v.v.i. / Institute of State and Law of the Czech Academy of Sciences, Czech Republic / E-mail: adam.dolezal@ilaw.cas.cz / ORCID: 0000-00026884-5451 / Research ID: 56521262500 


\section{Úvod}

Problematika informovaného souhlasu s poskytováním zdravotních služeb je v teorii i praxi již poměrně frekventovaným tématem. Dosud se však řada publikací shoduje zejména na nutnosti jeho existence, ovšem nezabývá se dalšími detaily. Jedním z problematických aspektů, u nás dosud jen okrajově rešených, je kvalifikace právní povahy informovaného souhlasu ${ }^{1}$. Ačkoliv se zejména $\mathrm{v}$ zahraniční literatuře vedou vášnivé diskuse o tom, jak právně kvalifikovat informovaný souhlas ${ }^{2}$, lze konstatovat, že česká právní doktrína vychází z toho, že informovaný souhlas je z pohledu práva právním jednáním ${ }^{3}, \mathrm{v}$ daném př́padě projevem vưle směřujícím ke vzniku práva zdravotnického pracovníka zasáhnout do integrity pacienta, tj. provést určitý diagnostický či terapeutický výkon. Tento názor zastává většina autorư ${ }^{4} \mathrm{~s}$ tím ovšem, že nijak nejsou analyzovány dopady této kvalifikace. S touto problematikou úzce souvisí i další okruh problémů a to skutečnost, že striktní aplikace pravidel o způsobilosti k právnímu jednání může vést de iure u některých jednotlivců k nemožnosti udělit informovaný souhlas se zdravotními službami, ačkoliv de facto udělení souhlasu nic nebrání. Typickým př́kladem mohou být osoby omezené ve svéprávnosti v určitých situacích. Často jsou tyto osoby omezeny ve svéprávnosti při poskytování zdravotních služeb velmi paušalizujícím způsobem, který je diskvalifikuje pro udělení informovaného souhlasu s jakoukoliv zdravotní péčí, ačkoliv jsou k poskytnutí určitého druhu zdravotních služeb zcela kompetentní.

Relativně vysokého standardu posuzování způsobilosti k právnímu jednání a s ním spojených problematických důsledků při aplikaci v oblasti rozhodování o poskytnutí zdravotních služeb si řada států byla vědoma, a proto se rozhodla požadavky na udělení informovaného souhlasu snížit a podřídit je jiným pravidlům ${ }^{5}$. Toto nazírání je však doposud českému právnímu prostředí cizí a lpění na striktním užití pravidel pro způsobilost k právnímu jednání způsobuje, že v některých př́padech může být nedostatečně

1 Blíže k tomu nap. DOLEŽAL, Tomáš. Právní povaha informovaného souhlasu a následky neúplného poučení z hlediska civilního práva. Casopis zdravotnickébo práva a bioetiky, 2019, roč. 9, č. 1, s. 55-72. ISSN 1804-8137.

2 Zejména v německé a rakouské oblasti jsou diskuze o právní povaze informovaného souhlasu velmi časté. O jejich komplikovanosti svědčí i fakt, že Koziol ve svém posledním článku z roku 2019 píše: „In der zivilrechtlichen Diskussion über die Einwiligung des Patienten wurde in grunlegenden Fragen bisher keine Einigung erzielt, insbesondere ist die rechtliche Qualifikation strittig. "[V civilněprávní diskusi o souhlasu pacienta nebylo dosaženo shody o zásadních otázkách, zejména je sporná jeho právní kvalifikace.] KOZIOL, Helmut. Fehlende Einwilligung des Patienten und Haftung in Österreich - Notwendigkeit neuer Lösungen? Medizinrecht, C. H. Beck, 2019, roč. 11, č. 37, s. 105-110, s. 105. ISSN 0723-8886.

3 Viz \545 ObčZ; Ohly k tomu uvádí: „Die Einwilligung ist also ein Rechtsgeschäft, wenn auch ein untypisches. "[Souhlas je tedy právním jednáním, i když atypickým.] OHLY, Ansgar. „Volenti non fit iniuria“: die Einwilligung im Privatrecht. Tübingen: Mohr Siebeck, 2002, 503 s., s. 25. ISBN 31-614-7793-6.

4 Např. ŠUSTEK, Petr a Tomáš HOLČAPEK. Informovaný soublas: Teorie a praxe informovaného soublasu ve zdravotnictví. 1. vyd. Praha: ASPI, 2007. ISBN 978-80-7357-268-6.

5 Viz dále v textu. 
respektováno právo člověka na autonomní rozhodnutí o svém životě a zdraví. Paradoxní přitom je, že se tak děje v zájmu ochrany práv tohoto člověka. Představme si člověka, který trpí závažnou psychickou poruchou (např. schizofreniî) a v př́padě ataky je výrazně snížena jeho schopnost (kompetence) se rozhodovat a jednat. S ohledem na možné neblahé důsledky právních jednání učiněných v této fázi, bude člověk, aby byl před negativními následky svých činů ochráněn, omezen v určitých záležitostech ve svéprávnosti. Jednou z těchto oblastí je i poskytování zdravotních služeb. Jak ale nahlížet na jednání člověka v tzv. intervalla lucida? Nebo ještě složitěji - jak hodnotit jednání, která přímo nesouvisí s důvodem omezení svéprávnosti, ke kterým je takový člověk zjevně schopen, ale přesto spadají do omezení ${ }^{6}$ ? Právě v těchto př́padech se ukazuje, že koncept způsobilosti k právním jednáním, tak jak je v právu používán, může být přiliš hrubý a schematický a nehodí se prŕliš $\mathrm{k}$ hodnocení schopnosti určitého člověka učinit rozhodnutí v konkrétní, specifické záležitosti týkající se vlastního zdraví.

V řadě států se historicky tato problematika projevila při udělování informovaného souhlasu dětmi ${ }^{7}$; v našem právním řádu se ale tento problém týká zejména osob omezených ve svéprávnosti. Cílem tohoto článku je upozornit na shora uvedenou problematiku a nastínit, zda stávající úprava závislosti posuzování schopnosti udělit informovaný souhlas na způsobilosti k právním jednáním dostatečně chrání zájmy dotčených subjektů, nebo by se nabízelo řešení vhodnější. Současně má článek poukázat na teoretické koncepce, na nichž jsou jednotlivé přístupy k posuzování způsobilosti založeny a podnítit odbornou diskusi nad koncepcí stávajícího řešení.

\section{Schopnost osoby jednat v právu a dalších disciplínách}

\subsection{Terminologická a významová vymezení}

Problematika schopnosti osoby se rozhodovat a jednat s relevantními důsledky jsou již odedávna předmětem jak právního, tak filozofického a etického bádání. Zatímco ve filozofické a etické literatuře se lze při označení této schopnosti setkat s termínem kompetence, $\mathrm{v}$ právnické literatuře se označení této schopnosti skrývá pod různými pojmy. $\mathrm{V}$ anglo-americkém kontextu se používá běžně termín legal capacity, v německy mluvících zemích se používá termínu Handlungsfähigkeit. V českém právu, vycházejícím z německé a rakouské právní tradice, pak způsobilost $\mathrm{k}$ právnímu jednání, př́padně termín svéprávnost ${ }^{8}$.

Problematika způsobilosti právně jednat má historické kořeny. Již v římském právu bylo podrobně rozlišováno, kdo je schopen o sobě rozhodovat samostatně z hlediska práva,

6 Např. shora uvedený pacient jde k lékaři kvưli chřipce nebo s bolestí zubů.

7 Srovnej kupř. Rakousko, Německo a Spojené království.

8 Ovšem tento pojem je širší, nebot’ zahrnuje nejen zpơsobilost k právnímu jednání, ale také deliktní způsobilost. 
tj. kdo má způsobilost k právnímu jednání a je osobou sui iuris, a kdo je při svém jednání podřízen jiné osobě (personae alieni iuris). V římském právu se také objevují dva teoretické koncepty ke stanovení způsobilosti právně jednat, tzv. statusový přístup (the status approach) a funkcionální prrístup (the functional approach). ${ }^{9}$ Statusový príistup se zaměroval na hraniční vymezení způsobilosti, tj. podle určitého pevně vymezeného a jasně daného statusu osoby, at' už se jednalo o věk ${ }^{10}$, postavení v rodině, či dokonce pohlavíi ${ }^{11}$. U statusového př́stupu se projevovala snaha práva vymezit přesnou hranici (zejména u věku) pro platné právní jednání osob. Taková hranice byla velmi užitečná pro zachování právní jistoty v právním styku, neodpovídala však plně realitě.

Naopak druhý přístup, funkcionální, se zaměřoval na posouzení rozumové a volní dispozice konkrétní osoby, př́padně její fyzické zralosti. Tento prrístup se odrážel např. v posuzování zdravotního stavu, zejména při nemocech duševních. Klasičtí autoři odmítali osobám šíleným přiznat vůbec vưlii ${ }^{12}$ a z toho důvodu nemohli činit samostatně právní jednání. Takovým osobám byl přidělován opatrovník (curator furiosi). ${ }^{13}$

Zatímco římskoprávní pojetí bylo výrazně ovlivněno statusovým př́istupem ${ }^{14}$, došlo postupem času k proměně posuzování způsobilosti k právnímu jednání a postupnému prolínání obou přístupů. Současné pojetí je většinou založeno zejména na funkcionálním př́istupu, který zohledňuje rozumové a volní schopnosti člověka.

9 JACKSON, Emily. Medical law: text, cases, and materials. 4. vyd. Oxford: Oxford University Press, 2016, 1029 s., s. 241. ISBN 978-0-19-874350-7.

10 Podstatná a zajímavá pro současné právní úpravy je otázka věku a jeho spojení se způsobilostí k právnímu jednání. Římské právo využívalo v rozvinutějším období statusového rozhraní, když do sedmi let věku je člověk dítě (infans) a jeho vůli právo neuznává. Postupem času však teorie připustila, že k jednoduchým právním jednáním (např. koupě cukrovî) může být dítě způsobilé. Dále pak právo rozlišovalo nedospělé (impuberes infanita maiores), kteři již měli způsobilost $\mathrm{k}$ některým právním jednáním. Za takto omezeně způsobilé osoby se proto považovali muži do 14 let věku a ženy do 12 let. Nad tuto věkovou hranici byly osoby považovány za dospělé (puberes). Původně ovšem římské právo vycházelo z funkcionálního pojetí, když podstatná byla fyzická zralost, tj. u muže okamžik, kdy může plodit děti. SALKOWSKI, Carl a Edward WHITFIELD. Institutes and history of Roman private law: with catena of texts. Clark, NJ: Lawbook Exchange, 1886, reprint 2008, 1048 s., s. 292 a násl. ISBN 15-847-7903-9.

11 Co se týče pohlaví, pak ženy nebyly považovány za právně rovnocenné mužům, protože je Ř́mané považovali za osoby lehkovážného ducha. Zákon 12 desek jim proto pro některá právní jednání ustavoval opatrovníka (tutela mulierum). GRUBBS, Judith E. Women and the Law in the Roman Empire: A Sourcebook on Marriage, Divorce and Widowhood. London, New York: Routledge, 2002, 344 s., s. 24 a násl. ISBN 0-415-15241-0.

12 Pomp.: „Furiosi [...] nulla voluntas est.“tj. „blázni nemaji vĩli“. D. 50, 17, 40. Podobně Gaius mluví o právních jednáních mentálně postiženého následovně - Gai. Iii. \106: „Furiosus nullum negotium gerere potest, quia non intelligit quid agat." $\mathrm{tj}$. „Blázen nemuiže uzavirat žádné smlowvy, protože nerozumi tomu, co čini."

13 Uznávalo se ovšem, že v určitých časových intervalech může být duševně nemocný při smyslech a v takovém prípadě mohlo mít jeho jednání právní účinky. Viz SALKOWSKI, WHITFIELD, 1886, op. cit., s. 324 a násl.

14 Osobou sui iuris byl v zásadě pouze pater familias - Srovnej ZIMMERMANN, Reinhard. The law of obligations: Roman foundations of the civilian tradition. Cape Town: Juta, 1990, 1241 s., s. 51 a násl. ISBN 90-654-4673-7. 


\subsection{Teoretické koncepty pro stanovení způsobilosti právně jednat v právu}

Obecně lze konstatovat, že v právu je posuzování způsobilosti k právním jednáním podmíněno existencí a kvalitou dvou základních složek - volní a rozumové. Jejich prítomnost u konkrétního člověka je v právu založena na různých domněnkách, přičemž koncepty odůvodňující existenci těchto domněnek mají původ v ostatních oborech. Často vycházejí z etických, psychologických, sociologických nebo medicínských modelů stanovení kompetence určité osoby. Tyto koncepty jsou ovšem často pro právníky neznámé a proto se pokusíme tyto koncepty popsat a ukázat jejich dopady do právní úpravy.

Statusový a funkcionální přístup jako základní teoretické koncepty posuzování způsobilosti právně jednat přetrvávají (v různých modifikacích a intenzitách) a jsou základem i dnešního př́stupu. Současně jsou tyto dva základní modely doplněny několika dalšími prrístupy, na nichž jsou současné právní úpravy založeny. V obecné rovině se jedná o rozlišování:

1. obecné (generálnî) a speciální kompetence;

2. stupňovité nebo hraniční kompetence;

3. kompetence závislé nebo nezávislé na následcích.

\section{Ad 1) obecná (generální) a speciální kompetence}

V literatuře o kompetenci se rozlišují dva přístupy - první prrístup vychází z obecné (generálnî) kompetence a druhý ze speciální kompetence. Přístup obecné kompetence vychází z předpokladu, že ten, kdo je kompetentní k činění rozhodnutí v obecných rozhodnutích v běžném každodenním životě, je kompetentní k činění rozhodnutí i v rámci specifických rozhodnutí. ${ }^{15}$ Podle této teorie jsou lidé bud' obecně schopní činit většinu rozhodnutí, nebo naopak nikoliv. Implicitně se tedy předpokládá, že základní schopností je schopnost rozhodnout se na základě zvážení relevantních informací. Za nekompetentní by měla být považována pouze osoba, která trpí určitou disfunkcí, tj. má specificky oslabené některé schopnosti. Tato teorie má nespornou výhodu v tom, že zjednodušuje situaci třetích osob, které vstupují do sociálních vztahů s osobou, u níž se kompetence posuzuje. Mưže zcela odhlédnout od kontextu a situace, ve které se posuzovaná osoba nachází. ${ }^{16} \mathrm{~V}$ řadě oblastí navíc vychází i z praktických zkušeností - osoba, která např. trpí demencí, bude většinou neschopna i běžných činností v životě.

Oproti tomu přístup požadující specifickou kompetenci pro určitou oblast rozhodování vyžaduje od člověka speciální schopnosti v konkrétním daném okamžiku. Zkoumány

15 Srovnej kupř. ABERNETHY, Virginia. Compasion, Control, and Decisions About Competency. American Journal of Psychiatry, 1984, roč. 141, č. 1, s. 53-58, s. 57 a násl. ISSN 0002-953X. DOI https://doi. org/10.1176/ajp.141.1.53; podobně také BEAUCHAMP, Tom L. a James Franklin CHILDRESS. Principles of biomedical ethics. 6. vyd. New York: Oxford University Press, 2009, xiii, 417 s. ISBN 978-0-19-533570-5.

16 WHITE, Becky Cox. Competence to consent. Washington, D.C.: Georgetown University Press, c1994, 208 s., ISBN 978-087-8405-596, s. 59. 
jsou právě tyto specifické schopnosti, pro rozhodování nap̌r. o udělení souhlasu se zdravotními službami není proto důležité, že osoba není schopna porozumět finančním transakcím a z toho důvodu ji byla částečně omezena svéprávnost v této sféře. Kompetence je tedy závislá na kontextu, na konkrétní situaci.

Rozdíl mezi obecnou kompetencí a specifickou kompetencí je důležitý, protože v medicínské praxi existují osoby, které jsou sice podle obecného př́stupu považovány za kompetentní, ale v určité situaci nejsou kompetentní k udělení informovaného souhlasu. ${ }^{17}$ Naopak jsou osoby, které by mohly být v konkrétním případě schopny udělit informovaný souhlas, ale v obecné rovině za kompetentní nejsou považovány ${ }^{18}$.

\section{Ad 2) stupňovitá (degree concept) nebo hraniční (threshold concept) kompetence}

Kompetence může být vnímána jako koncept stupňovitý, tj. jako koncept, který může nabývat více a více na síle podle míry schopností konkrétní osoby. ${ }^{19}$ Kompetence v tomto konceptu roste od úplné nekompetence až k absolutní kompetenci. Koncept stupňovité kompetence respektuje, že odlišní jedinci mají odlišnou kompetenci, protože mají i odlišnou míru schopnosti se rozhodovat. I samotná osoba může mít v některých př́padech rozličný stupeň kompetence, nap̌r. ráno a večer.

Oproti stupňovité koncepci lze rozlišit často užívaný koncept hraniční kompetence (treshold competence). Tato koncepce je koncepcí bud' - anebo, tj. osoba kompetentní bud' je, anebo není. Podle tohoto konceptu je jakákoliv osoba, jejíž schopnosti překročí určitou hranici, zcela kompetentní. Naopak osoba, která hranice nedosahuje, je nekompetentní. Výhoda této teorie je, že dokáže poměrně jednoduše rozlišit osoby, které jsou kompetentní, od těch, které kompetentní nejsou. Rozhodující je míra schopností, která přesahuje určitou mez. Rozhodující ovšem může být i jiné kritérium, jako je např́íklad věk osoby. Právo tuto koncepci velmi často a úspěšně užívá - např́íklad věkové hranice, které určují právní způsobilost.

Empirické zkušenosti více odpovídá koncept stupňovité kompetence. Hraniční koncept má ovšem tu výhodu, že je poměrně ostře nastavena hraniční linie a osoba kompetentní je od osoby nekompetentní formálně snadno rozlišitelná. Problém s hraniční teorií je ten, že nastavená hranice je velmi často arbitrární a založená na pouhé konvenci. ${ }^{20}$

17 Např. osoby v šoku, osoby pod vlivem sedativ, atp.

18 Např. děti mající k určitým jednáním dostatečnou rozumovou vybavenost.

19 Např. BEAUCHAMP, Tom L. a Laurence MCCULLOUGH. Medical ethics: the moral responsibilities of physicians. Englewood Cliffs, N.J.: Prentice-Hall, 1984, s. 120. ISBN 01-357-2652-2; Kritický vůči hraniční koncepci kompetence je kupř. den Hartogh, který se prriklání ke kompetenci stupňovité. HARTOGH, G. den. Do we need a threshold conception of competence? Medicine, Health Care and Philosophy, 2016, roč. 19, č. 1 , s. $71-83$.

20 Tak tomu je ovšem v medicíně velmi často - např́klad teplota 36,9 je ještě přijatelná a teplota 37,1 již nikoliv. 


\section{Ad 3) kompetence závislá nebo nezávislá na následcích}

Konečně posledním zásadním rozlišením je rozlišení kompetence podle toho, zda má být posuzována podle míry rizika následků jednání. Teorie založená na následcích ve stručnosti tvrdí, že čím je riziko negativních následků větší (resp. čím je následek závažnějšî), tím musí mít jednající více schopností. Mezi jeho schopnostmi a stupněm rizika musí být tedy přímá úměrnost, vyšší míra rizika značí vyšší míru schopností. Podle této definice se kompetence mění podle vážnosti situace. ${ }^{21} \mathrm{~V}$ oblasti zásahů do integrity např. některé osoby s omezenými schopnostmi mohou být kompetentní k nízce rizikovým zásahům, ale už nikoliv k zásahům spojeným s vyšší mírou rizika. ${ }^{22}$

Teorie nezávislá na následcích odmítá prričítat následkům jakoukoliv relevanci. Kompetentní osoba je stejně tak schopna posoudit navrhovaný postup léčby u pouhé chřipky, jako postup v prrípadě léčby onkologického onemocnění. Možné následky nemoci nebo rizika léčby nemají vliv na posuzování kompetence. ${ }^{23}$

Teorie závislá na následcích více zdůrazňuje ochranu osoby, tj. princip beneficence. Teorie odhlížející od následků naopak klade důraz na autonomii osoby. Zajímavé je, že přestože civilní právo je založeno na ochraně autonomie člověka, bývá často možný škodlivý následek a jeho riziko zohledňován při vymezení způsobilosti osoby právně jednat. ${ }^{24}$

\subsection{Promítnutí teoretických konceptů do právní úpravy $\mathrm{OZ}$}

Ačkoliv civilistická právní dogmatika nepracuje výslovně s jednotlivými teoretickými koncepty kompetence, lze konstatovat, že se tyto koncepty promítají do úpravy občanského zákoníku (dále je „OZ“) a zákonodárce s nimi (byt’ nevědomky) při tvorbě OZ pracoval. Právní úprava $\mathrm{OZ}$ vychází z kombinovaného př́istupu ke zkoumání kompetence osoby a je směsicí statusového a funkcionálního př́stupu.

21 Drane např́íklad podle toho rozebírá tři stupně kompetence podle míry rizik. Použivá proto termín „sliding scale concept“. Srovnej DRANE, James F. Competency to give an informed consent: A model for making clinical assessments. JAMA, 1984, roč. 252, č. 5, s. 925-927. ISSN 1538-3598; podrobněji jej rozebírá v pozdějším článku z roku 1985: DRANE, James F. The Many Faces of Competency. The Hastings Center Report, 1985, roč. 15, č. 2, s. 17-21. ISSN 1552-146X; Z modernějších navazujících autorů užívající této teorie srovnej kupř. ÁLVARO, Luis C. Competency: General principles and applicability in dementia. Neurología, 2012, č. 27, s. 290-300; nebo LAHEY, Tim a Glyn ELWYN. Sliding-Scale Shared Decision Making for Patients With Reduced Capacity. AMA Journal of Ethics, 2020, roč. 22, č. 5, s. E358-364.

22 Nepř́mo tuto teorii podporuje např. FADEN, Ruth R. a Tom BEAUCHAMP. A bistory and theory of informed consent. New York: Oxford University Press, c1986, xv, 392 s., s. 289. ISBN 01-950-3686-7.

23 "If autonomy is to have any meaning, then patients must be permitted to disagree, even if that disagreement is associated with the risk of death. "ETH, Spencer. Competency and Consent to Treatment. JAMA, 1985, roč. 253, č. 6, s. 778-779, s. 779. ISSN 1538-3598. Podobně odmítavý je k zohledňování rizik zákroků i Malcolm Parker. Srovnej PARKER, Malcolm. Competence by consequence: ambiguity and incoherence in the law. Medicine and Law, 2006. roč. 25, č. 1, s. 1-12.

24 Viz níže v tomto textu. 
V OZ je svéprávnost upravena v \15 odst. 2 a je definována jako způsobilost nabývat pro sebe vlastním právním jednáním práva a zavazovat se k povinnostem (právně jednat $)^{25}$. OZ rozlišuje úplnou svéprávnost, omezenou svéprávnost a částečnou svéprávnost. Plnou svéprávnost nabývá člověk podle \30 OZ zletilostí, uzavřením manželství nebo emancipací. Zletilosti se nabývá dovršením osmnáctého roku věku. OZ je tak postaveno v oblasti posuzování způsobilosti k právnímu jednání na statusovém př́stupu, založeném na konceptu tzv. hraniční kompetence. Podle tohoto konceptu je jakákoliv osoba, která překročí věkovou hranici 18 let (nebo uzavře manželstvî), zcela kompetentní. Děti nebo zletilé osoby, u nichž byla svéprávnost omezena na základě rozhodnutí soudu, jsou omezeně svéprávné, i když koncepce této omezené svéprávnosti je v obou př́padech odlišná. Zatímco u dětí je prostřednictvím \31 OZ modifikována jejich nesvéprávnost ve prospěch omezené svéprávnosti26, u zletilých osob, které jsou neschopné postarat se o vlastní záležitosti, je naopak modifikována jejich svéprávnost na omezenou svéprávnost ${ }^{27}$. Oba tyto př́pady jsou ale založeny na shodném, funkcionálním prŕístupu k posuzování způsobilosti k právnímu jednání a pro posouzení schopnosti jednat hraje významnou roli speciální kompetence, tj. posouzení, zda osoba je kompetentní $\mathrm{k}$ činění rozhodnutí i v rámci specifických rozhodovacích procesů - např. osoba s určitou duševní poruchou může být nekompetentní ve vztahu k rozhodování o léčbě této duševní poruchy, ale kompetentní k jiným právním jednáním včetně rozhodování o jiných poskytovaných zdravotních službách.

V OZ dochází relativně často také k modifikaci funkcionálního př́stupu prostřednictvím teorie posuzování kompetence člověka v závislosti na následcích. Jedná se zejména o ustanovení \95 OZ, které schopnost osoby udělit souhlas se zákrokem na svém těle podmiňuje povahou následků - ,jedná-li se o qákrok nezanechávajicí trvalé nebo qávažné následky“.28

\subsection{Zvláštnosti problematiky posuzování schopnosti udělit informovaný souhlas při poskytování zdravotních služeb}

Jak bylo ukázáno shora, pracuje $\mathrm{OZ}$ v rámci posuzování schopnosti člověka udělit souhlas se zásahem do integrity s různými přístupy. Tyto př́istupy jsou velmi důležité i pro oblast posuzování schopnosti udělit souhlas s poskytováním zdravotních služeb, nebot'

\footnotetext{
$25 \mathrm{~V}$ pojmu svéprávnost je zahrnuta nejen způsobilost k právnímu jednání, ale také deliktní způsobilost. S ohledem na zaměřní tohoto článku se zabýváme pouze zpơsobilostí k právnímu jednání.

26 \ 31 OZ: „Má se za to, že každý nezletilý, který nenabyl plné svéprávnosti, je zpuisobilý k právním jednáním co do povahy priméreným rozumové a volni vyspèlosti nezletilých jeho věkeu."

$27 \int 55$ a 56 OZ.

28 Obdobné platí i pro \101 OZ, které ovšem tuto podmínku klade pro rozhodování zástupce.
} 
stávající úprava zákona č. 372/2011 Sb. o zdravotních službách (dále jen také „ZZS“) neobsahuje zcela svébytnou úpravu a vychází z úpravy $O Z^{29}$.

V medicínské praxi je absolutní většina př́padů tzv. „zjevných“ a není zde důvod k posuzování schopnosti člověka udělit souhlas s poskytováním zdravotních služeb. V klinické praxi se běžně pracuje s konceptem presumpce kompetentního pacienta. Tedy pacient je kompetentní (způsobilý udělit souhlas), pokud není prokázáno jinak. Tato presumpce je předpokládána i právními úpravami. ${ }^{30} \mathrm{U}$ presumpce je však třeba mít na vědomí, že se jedná pouze o nastavenou fikci, která může a nemusí odpovídat reálné kompetenci pacienta. Většina zdravotníků tak vychází ze shora uvedené presumpce kompetentního pacienta a teprve $\mathrm{v}$ určitých situacích se zabývají zkoumáním kompetence pacienta k udělení souhlasu. V literatuře jsou uváděny zejména tyto čtyřri situace ${ }^{31}$ :

- věk pacienta je nízký;

- pacient je soudním rozhodnutím omezen ve svéprávnosti;

- pacient je osobou trpící nemocí, která s sebou obvykle přináší i snižování mentální kapacity, napr. demence, Alzheimerova choroba, některé psychiatrické choroby, apod., nebo je dočasně pod vlivem léčiv;

- pacient odmítá navrženou léčbu a jeho odmítnutí se ve světle poskytnutých informací jeví jako iracionální. ${ }^{32}$

Každopádně proto, aby zdravotničtí pracovníci mohli vycházet z presumpce kompetentního pacienta, potřebují mít nastavena kritéria, z jejichž existence mohou usuzovat na kompetenci určitého pacienta, resp. při jejich neexistenci nebo existenci v omezeném rozsahu kompetenci konkrétního pacienta podrobit přezkumu.

29 Ustanovení \ 35 ZZS v odst. 1, věta třetí stanoví: „Pro vysloveni soublasu s poskytnutim zdravotnich služeb nęletilému pacientovi se pouřiji právni predpisy upravujici svéprávnost fyzických osob s tím, že nezletilému pacientovi lze zamýšlené zdravotni služby poskytnout na základè jeho soublasu, jestliže je provedeni takovébo úkonu primèrené jeho rozumové a volni vyspělosti odpovidajici jeho věku. "Pro osoby omezené ve svéprávnosti pak ustanovení \35 odst. 4 ZZS stanoví, že „Jde-li o pacienta s omezenou svéprávností, odstavce 1 až 3 se použiji obdobněs tím, že věke pacienta se nezobledñuje."

30 Srovnej např. zákon Spojeného království Mental Capacity Act z roku 2005, kde je tato presumpce explicitně vyjádřena.

31 WEAR, Stephen. Informed consent: patient autonomy and physician beneficence within clinical medicine. Boston: Kluwer Academic Publishers, 1993, 168 s., s. 49. ISBN 07-923-2029-8.

32 ETH, 1985, op. cit., s. 778-779; Podobně i Grisso s Appelbaumem ve své klasické publikaci o kompetenci pacientů GRISSO, Thomas a Paul S. APPELBAUM. Assessing competence to consent to treatment: A guide for physicians and other health professionals. Oxford University Press: New York, 1998, 211 s. ISBN 978-0-19-510372-4. 
Podstatnou roli při tomto hodnocení hraje zejména vytyčení toho, k čemu má být pacient vỉbec kompetentni. ${ }^{33}$ Opět se zde využívá tzv. task definice, tj. vytyčení kompetence prostřednictvím úkolu, který má být splněn. Pro poskytnutí souhlasu se zdravotní péčí jsou standardně vyžadovány následující specifické schopnosti:

- schopnost pracovat s informacemi, zejména schopnost informace prijímat, rozumět jim a udržet je relevantní dobu v paměti;

- Kognitivni schopnosti rozuažování, zejména rozvažování o důvodech, kognitivní analýza alternativ, schopnost jejich řazení podle vlastní důležitosti a hodnot, zejména vztahovat je k vlastnímu integrovanému jả ${ }^{34}$ a jeho hodnotové struktuře;

- rozhodovaci schopnosti, tj. schopnost se v konkrétní situaci rozhodnout ${ }^{35}$ (napr. jsou osoby s patologickou neschopností provést rozhodnutí a nést za něj důsledky), schopnost i přes pochybnosti se zavázat k takovému rozhodnutí.

Konečně kromě rozumové vybavenosti hrají velkou roli i emoce. Kompetence je nejen věcí rozumu, ale je i věcí emocionálního stavu. Emoce mají totiž velký vliv na rozhodovací schopnosti ${ }^{36}$ a mohou mít i zásadní vliv na kompetentnost pacienta.

Výraznou komplikací při posuzování kompetence je také časová proměnlivost schopností u jednotlivého člověka. ${ }^{37}$ Lze ji brát ve smyslu kontinuální proměny během lidského života (může mít např. povahu sinusoidy, kdy v dětství narůstá a ve stáří může od určitého věku poklesávat), ale i jako proměnlivost u jednoho pacienta v rámci jeho psychické nemoci, kdy se mohou střídat relativně lucidní stavy se stavy, kdy je osoba zcela nekompetentní k jakémukoliv vyjádření své vůle (nap̌r. v určitých stadiích Alzheimerovy choroby, př́padně schizofrenie, kdy pacient je ve fázi ovlivněné bludy, apod., ale i např́iklad ovlivnění léčivou látkou mající dočasný dopad na kognitivní funkce).

33 Je potřeba rozlišovat mezi definování kompetence (teoretický koncept, konceptuální analýza) a měřením kompetence (empirické testy kompetence). Praktický koncept vychází nutně z teoretické koncepce je totiž nutné vědět, které kapacity se mají vůbec měřit. Bez definice nejsou možné relevantní testy, protože není zřejmé, jaké kapacity se mají zkoumat; tj. i podmínky, při kterých je informovaný konsenzus validní (morálně i právně).

$34,[. .$.$] determine whether the person in his present state is expressing preferences that are continuous with those he has$ expressed in the past. If the patient is judged to be acting from his ,true self', then on this standard the person is competent. "BAUMGARTEN, Elias. The concept of 'competence' in medical ethics. Journal of medical ethics, 1980, roč. 6, č. 4, s. 180-184, s. 181. ISSN 0306-6800. DOI https://doi.org/10.1136/jme.6.4.180

35 Určitým paradoxem je, že většina pacientů nepovažuje sama sebe za osobu, která $\mathrm{v}$ praxi rozhoduje o postupu léčby. Srovnej kupř. LIDZ, Charles W. et al. Barriers to Informed Consent. Annals of Internal Medicine, 1983, roč. 99, č. 4, s. 539-543, s. 541. ISSN 0003-481. DOI https://doi. org/10.7326/0003-4819-99-4-539

36 NAKONEČNÝ, Milan. Lexikon psychologie. Praha: Vodnář, 1995, 397 s., s. 48 a násl. ISBN 80-85255-74-X.

37 BEAUCHAMP, MCCULLOUGH, 1984, op. cit., s. 119. 


\section{Způsobilost právně jednat a udělit informovaný souhlas z komparativního pohledu}

V řadě zemí se postupem času ukázalo, že striktní aplikace pravidel pro posuzování způsobilosti právně jednat i na situace udělení souhlasu se zákrokem je př́liš paušalizující a nedostatečně respektuje schopnosti člověka v konkrétním př́padě. Jednalo se zejména o př́pady posuzování způsobilosti děti ${ }^{38}$ nebo osob se zdravotním hendikepem ${ }^{39}$. Tyto země se následně rozhodly bud’ plně oddělit posuzování způsobilosti k právním jednáním od způsobilosti $\mathrm{k}$ udělení souhlasu $\mathrm{k}$ medicínskému zákroku (např. VB), nebo zavést zvláštní požadavky na zpơsobilost k udělení souhlasu k medicínskému zákroku (např. Německo, Rakousko).

\section{Anglie}

Pro účely zdravotních právních jednání pak v Anglii vzniklo několik zákonů, poslední z nich je Mental Capacity Act z roku $2005^{40}$. Ten již ve svém prvním článku stanoví následující základní principy, které jsou základním vodítkem pro posuzování způsobilosti udělit souhlas u pacientů. Předně právo vychází z presumpce kompetentního pacienta, dokud se neprokáže opak. Dále je podporována nápomoc při rozhodování. A konečně je stanoveno, že nemoudrá rozhodnutí nejsou důvodem pro nezpůsobilost ${ }^{41}$.

Anglické právo tedy prrijalo kombinaci statusového přístupu a funkcionálního přístupu při zkoumání právní způsobilosti (capacity) jednajícího v oblasti poskytování zdravotní péče; u všech zletilých se předpokládá, že jsou způsobilí. U všech dětí mladších šestnácti let ${ }^{42}$

38 Např. Velká Británie, Německo, Rakousko - pro stručný přehled viz DOLEŽAL, Tomáš. Způsobilost nezletilých udělit souhlas s poskytováním zdravotních služeb. Casopis żdravotnického práva a bioetiky, 2018, roč. 8 , č. 1, s. 48-61. ISSN 1804-8137.

39 Významným dokumentem pro posuny na vnitrostátní úrovni byla Úmluva OSN o právech osob se zdravotním postižením.

40 Podrobněji k tomuto zákonu viz MARSHALL, Helen. The Mental Capacity Act: a review of the current literature. British journal of community nursing, 2016, roč. 21, č. 8, s. 406-410. ISSN 1462-4753; a také JACKSON, Emily. Medical law: text, cases, and materials. 4. vyd. Oxford: Oxford University Press, 2016, 1029 s., s. 241 a násl. ISBN 978-0-19-874350-7.

41 The Mental Capacity Act: „1 The Principles

(1) Pro úcely tohoto zákona jsou aplikovány následujuci principy.

(2) Předpokládá se, že osoba má zpisobilost (kapacitu), dokud se neprokáže, že tuto zprisobilost postrádá.

(3) S osobou nebude jednáno jako s osobou nezpuisobilou činit vlastni rozhodnutí, dokud nebyly učinèny veškeré pomocné kroky a ty se ukázaly jako neúspěsné.

(4) S osobou nebude jednáno jako s osobou nezpiosobilou činit vlastní rozhodnuti pouze z toho dìvodu, že čini nemondrá roz̧odnutí.

(5) Jednání, nebo roz̧hodnutí, činèná za osobu, u ní̌ je shledána nezpuisobilost, musí být činèna v souladu s nejlepšimi zájmy osoby.

(6) Pred tim, nežje vykonáno jednáni nebo učinèno rozhodnutí, je třeba zvážit účel, pro nèjž je potrebné, nemưže být docilen jinými prostredky, které by méné zasabovaly do práv a svobod osoby."

42 The Mental Capacity Act se nevztahuje na osoby mladší 16 let. 
musí být způsobilost posuzována a v zásadě se tedy vychází z opačné vyvratitelné právní domněnky, tj. že způsobilost postrádaji ${ }^{43}$. Ačkoliv tyto právní domněnky jsou založeny na statusovém př́stupu, jsou pouhým výchozím předpokladem, který může být pozměněn na základě prokázání aktuální způsobilosti zkoumané osoby ${ }^{44}$.

Podobně i v americkém právním prostředí je předpokládáno, že dospělá osoba je kompetentní, pokud se neprokáže opak. ${ }^{45}$

\section{Německo a Rakousko}

V Německu a Rakousku byla tato problematika předmětem dlouho probíhajících debat. Při vědomí specifičnosti problematiky udělování souhlasu se zdravotní péčí je v současné době rozlišováno mezi způsobilostí člověka právně jednat („,Handlungsfähigkeeit“) a způsobilostí udělit souhlas („Einwilligungsfähigkeit“).

V Německu, v rámci novelizace BGB prostřednictvím tzv. „Patientenrechtegesetz." v roce 2013, bylo do BGB přidáno ustanovení \ 630d BGB, které explicitně hovoří o způsobilosti udělit souhlas (,ist der Patient einwilligungsunfähig“) a tím zakotvuje doposud pouze judikatorně dovozovanou odchylku od požadavků kladených na schopnosti člověka pro udělení souhlasu se zdravotní péčí. Člověk tedy nemusí mít způsobilost právně jednat („Handlungsfähigkeit”), ale stačí pouze způsobilost udělit souhlas („Einwilligungsfähigkeit“). Podle konstantní judikatury je způsobilý k udělení souhlasu ten, kdo je schopen pochopit způsob, význam a dopady (rizika) zdravotních opatření ${ }^{46}$.

Obdobně v Rakousku došlo již v roce 2001 k novelizaci ABGB a prostřednictvím Kindschaftsrechts Änderungsgesetz v ustanovení \146c ABGB byla upravena zpơsobilost dětí $\mathrm{k}$ udělení souhlasu s lékařským zákrokem. V současné době se tato úprava nalézá v ustanovení \173 ABGB a stanoví, že souhlas se zákrokem může udělit dítě, které je způsobilé se rozhodnout (,EEntscheidungsfähigkeit“). Pro udělení souhlasu tak nenî nezbytná způsobilost k právnímu jednání, ale schopnost pochopit sdělované (schopnost rozvažovánî) a schopnost rozhodování v konkrétním případě („auf die Einsichts- und

43 Blíže k tomu např. LAING, Judith M., Jean MCHALE, Ian KENNEDY a Andrew GRUBB (eds.). Principles of medical law. 4. vyd. Oxford, United Kingdom: Oxford University Press, 2017, 1328 s., s. 458 a násl. ISBN 978-0-19-873251-8; Zásady pro posuzování kompetence u dětí do 16 let jsou obsaženy v prrípadu Gillick proti West Norfolk and Wisbech AHA and DHSS z roku 1985.

44 JACKSON, Emily. Medical law: text, cases, and materials. 4. vyd. Oxford: Oxford University Press, 2016, 1029 s., s. 242. ISBN 978-0-19-874350-7.

45 Srovnej podrobněji President's Comission for the Study of Ethical Problems in Medicene and Biomedical and Behavioral Research. Making Health Care Decissions. Volume One: Report. Washington: U.S. Governement Printing Office, 1982, 196 s., s. 56; Srovnej také rozhodnutí Lotman proti Security Mutual Life Ins. Co, 478 F 2 d 868 (3d cir. 1973).

46 „Einwilligungsfäbig ist, wer Art, Bedeutung und Tragweite (Risiken) der ärzttlichen Maßnahme erfassen kann. "BGH, Urteil vom 28. 11. 1957, 4 Str 525/57; BGH 16. 11. 1971 - VI ZR 76/70; OLG Hamm FGPrax 1997, 64. 
Urteilsfähigkeit im Einzelfall abzustellen ist")47. Tyto požadavky jsou aplikovány i na dospělé osoby, které nejsou způsobilé k právním jednáním. Proto po zavedení tohoto ustanovení se v rámci rakouské dogmatiky rozproudila živá diskuse o kritériích kladených na udělení souhlasu $\mathrm{k}$ lékařskému zákroku. V rámci části odborné veřejnosti pak převládl názor, že se jedná o způsobilost právně jednat ve zvláštních záležitostech („Handlungsfähigkeit in besonderen Angelegenheiten") ${ }^{48}$ a nejsou na ni kladeny takové požadavky jako na vlastní způsobilost k právnímu jednání (,Handlungsfähigkeit“).

V př́padě obou států tak dochází k tomu, že schopnost udělit souhlas s lékařským zákrokem není vázána na (ani podmíněna) způsobilost k právnímu jednání, ale na schopnost pacienta pochopit komplexnost konkrétního lékařského zákroku. Výsledkem tohoto pojetí je, že tato schopnost je situačně podmíněna a může být v konkrétní situaci dána i u osob, které jsou omezeny ve svéprávnosti, a naopak může chybět u osob, které jsou svéprávné.

\section{Praktické důsledky oddělení způsobilosti právně jednat a udělit informovaný souhlas v českém prostředí}

Jak již bylo uvedeno shora, byla v některých státech impulsem k oddělení způsobilosti právně jednat a udělit informovaný souhlas snaha zajistit dětem dostatečnou rozhodovací pravomoc $\mathrm{v}$ záležitostech svého zdravotního stavu v závislosti na vzrůstajících rozumových schopnostech. V ČR je v právních předpisech zohledněna rozhodovací schopnost dětí dostatečně ${ }^{49}$, nebot' OZ i ZZS pracují s proměnlivou rozhodovací schopností v závislosti na rozumové a volní vyspělosti konkrétního dítěte. Zásadní problém vazby schopnosti udělit souhlas k lékařskému zákroku na zpơsobilost k právnímu jednání (svéprávnost) tak vyvstává pouze u osob s omezenou svéprávností. A i zde se domníváme, že z teoretického hlediska, jde o problém pouze zdánlivý. Praxe je ovšem rozdílná. ${ }^{50}$

47 GLEIXNER-EBERLE, Elisabeth. Die Einwilligung in die medizinische Behandlung Minderjähriger. Eine arætrechtliche Untersuchung im Rechtsvergleich mit Österreich und der Schweiz sowie mit Blick auf das Internationale Privat- und Strafrecht. Berlin Heidelberg: Springer-Verlag, 2014, 554 s., s. 42. ISBN 978-3-642-41930-0; nebo JUEN, Thomas. Aræthaftungsrecht.Die qivilrechtliche Haftung des Arztes für den Behandlungsfehler - der Aræ̧thaftungsprozess in Österreich. Wien, Manz Verlag, 2005, s. 322, s. 42. ISBN 978-3-214-10180-0.

48 „Die Rede ist von einer, besonderen Art der Geschäftsfähigkeit‘, bei der das grundsätzliche Erfordernis der Geschäftsfähigkeit durch die Regelung des $\int 146 c$ ABGB modifiziert sei.“ [Mluvíme o „zvláštním druhu způsobilosti k právnímu jednání“, jímž je modifikována obecná zpơsobilost k právnímu jednání upravená ustanovením \146c ABGB.] KOPETZKI, Christian. In: KOPETZKI, Christian (Hrsg.). Einwilligung und Einwilligungsfähigkeit. Wien: Manz Verlag, 2002, s. 86, s. 2. ISBN 978-3214069285.

49 Viz DOLEŽAL, 2018, op. cit.; Samožrejmě se lze ptát, zda jsou rozhodovací schopnosti dětí dostatečně zohledňovány i v praxi. Zde jsme přesvědčeni, že participační práva i možnosti samostatného rozhodování jsou často přehlíženy.

50 Relativně běžně je ve zdravotnických zařizeních vyžadován souhlas opatrovníka se všemi zdravotními zákroky z důvodu široce definovaného omezení v soudních rozhodnutích. 
V situaci, kdy české právo již nezná institut zbavení způsobilosti k právním úkonům ${ }^{51}$, ale operuje pouze s institutem omezené svéprávnosti, je na soudech, aby důsledně definovaly právní jednání, ke kterým dotčený člověk není způsobilý. Paušalizující výroky rozhodnutí o omezení svéprávnosti $\mathrm{v}$ oblasti udělení informovaného souhlasu při poskytování zdravotních služeb nemohou obstát a omezení musí být vždy definováno konkrétněji ${ }^{52}$. Ve světle shora uvedených teorií kompetence je totiž zjevné, že pacient nemusí být zpơsobilý udělit souhlas s určitým lékařským zákrokem, ale u jiného nevznikají pochybnosti o způsobilosti takový souhlas udělit. Obecně vymezené omezení svéprávnosti v oblasti udělení informovaného souhlasu při poskytování zdravotních služeb nerespektuje důstojnost člověka a jeho autonomii. Při obecně vymezeném omezení svéprávnosti $\mathrm{v}$ rozhodnutí by tak $\mathrm{v}$ praxi mělo docházet $\mathrm{k}$ přezkoumání kompetence daného pacienta $\mathrm{v}$ konkrétním okamžiku a ke konkrétnímu zákroku, a pokud bude tato kompetence dostatečná, není důvodu, aby nemohl i pacient omezený ve svéprávnosti udělit informovaný souhlas sám. Tento závěr vyplývá i z čl. 12 odst. 2 Úmluvy o právech osob se zdravotním postižením ${ }^{53}$ a lze s jistou mírou kreativity dovozovat i z ustanovení \ 35 ZZS odst. 1 věta třetí (ve spojení s odst. 4 předmětného ustanovenî) ${ }^{54}$, které odkazuje na rozumovou a volní vyspělost pacienta ${ }^{55}$.

\section{Závěr}

Problematika posuzování způsobilosti k udělení informovaného souhlasu s poskytováním zdravotních služeb je relativně komplikovanou záležitostí. Odejmutí možnosti samostatného rozhodnutí v této oblasti se významně dotýká samé podstaty člověka a jeho směřování. Proto by takové př́pady měly být zcela výjimečné a měla by jim předcházet snaha o docílení samostatného rozhodnutí, a to i prostřednictvím různých forem nápomoci při rozhodování ${ }^{56}$.

51 Viz původní S OZ 1964.

52 Např. by u psychiatrických pacientů dostačovalo omezení na oblast poskytování psychiatrické péče apod.

53 Úmluva o právech osob se zdravotním postižením publikovaná pod č. 10/2010 Sb. m. s.

54 Lze tak učinit při oproštění se od doslovného výkladu \35 ZZS odst. 1 věty třetí, která odkazuje na právní předpisy upravující svéprávnost fyzických osob a současně odkazuje na rozumovou a volní vyspělost. Zde je však situace odlišná od nezletilých, nebot’ zletilé osoby jsou v konkrétní oblasti omezovány ve svéprávnosti právě pro neschopnost postarat se o vlastní záležitosti, tj. nedostatečnou rozumovou a volní vyspělost. V situaci, kdy tedy soud omezí svéprávnost člověka v rozsahu udělení informovaného souhlasu při poskytování zdravotních služeb, je pak pro poskytovatele zdravotních služeb př́i znalosti tohoto rozhodnutí velmi obtížné dovozovat dostatečnou rozumovou a volní schopnost pro udělení informovaného souhlasu s poskytnutím určité zdravotní služby.

55 „pacientovi lze zamýšlené żdravotni služby poskytnout na základě jeho soublasu, jestliže je provedeni takovébo úkonu primèrené jeho rozumové a volni vyspèlosti".

56 Viz rozsáhlé možnosti stávajícího OZ. 
Při vědomí specifičnosti udělování informovaného souhlasu při poskytování zdravotních služeb dochází z komparativního pohledu často k odchýlení od běžných pravidel pro posuzování způsobilosti k právnímu jednání a na způsobilost (kompetenci) k udělování informovaného souhlasu jsou kladeny nižší nároky - dưležité je, aby pacient byl v konkrétním prípadě schopen pochopit způsob, význam a dopady (rizika) navrhovaných zdravotních služeb. Tím také dochází v rovině právní dogmatiky k oddělení institutu svéprávnosti a schopnosti udělit informovaný souhlas. Navrhovaný př́stup klade samožrejmě v běžné medicínské praxi vyšší nároky na přezkoumávání aktuálních rozumových a rozhodovacích schopností pacientů, u nichž existují pochybnosti o jejich kompetenci, ale lépe respektuje základní principy soukromého práva, zejména pak právo člověka na autonomní rozhodnutí o svém životě a zdraví.

Krátká analýza ukázala, že právní úprava OZ vychází z jednotlivých teoretických konceptů kompetence. Významnou skutečností, která se objevuje v moderním chápání způsobilosti k udělování informovaného souhlasu, je, že tato způsobilost je na rozdíl od obecně koncipované způsobilosti k právnímu jednání, tzv. task oriented, tj. je spjata s určitou činností či úkolem a může být proměnlivá, proto musí být přezkoumávána vždy s ohledem na konkrétní situaci a čas.

$\mathrm{V}$ rámci české právní a medicínské praxe se důsledky oddělení způsobilosti právně jednat a udělit informovaný souhlas mohou projevit zejména v rámci posuzování schopnosti udělit informovaný souhlas u osob omezených ve svéprávnosti. V rámci respektu $\mathrm{k}$ autonomii člověka a jeho důstojnosti je tak nutno vycházet z toho, že i u osob omezených ve svéprávnosti by mělo být respektováno jejich autonomní rozhodování, pokud jsou k takovému rozhodnutí kompetentní. 